\title{
THE CURRENT STATE \\ OF PHYTO-COENOLOGICAL RESEARCH \\ IN THE “IRON GATES” DANUBE GORGE \\ (BANAT, ROMANIA)
}

Constantin DR $\breve{A G U L E S C U *}$

* "Lucian Blaga" University of Sibiu, Faculty of Sciences, Department of Ecology and Environment Protection, Dr. Ioan Raţiu Street 5-7, Sibiu, Sibiu County, Romania, RO-550012, constantindragulescu@yahoo.ro

DOI: 10.1515/trser-2015-0033

KEYWORDS: Romania, Danube Gorge, phyto-coenology, natural park, vegetation, research history.

\section{ABSTRACT}

The author of the study writes a concise history of the phyto-coenological research conducted previously in the Danube Gorge; he notes the papers and the respective publishing years for the botanists who contributed with research to the knowledge of the cormophyte vegetation along the aforementioned sector of the Danube River.

55 important papers are highlighted, authored by fifty-four specialists in the years 1931-2006.

ZUSAMMENFASSUNG: Gegenwärtiger Stand der phytozönologischen Forschungen im Durchbruchtal der Donau (Banat, Rumanien).

Der Verfasser liefert einen geschichtlichen Überblick über die im DonauDurchbruchtal (Cazan-Pass und Eisernes Tor) durchgeführten phytozönologischen Untersuchungen und erwähnt in chronologischer Reihenfolge, nach dem Erscheinungsjahr der Arbeiten, die Botaniker, die durch ihre Forschungen zur Kenntnis der Vegetation aus diesem Abschnitt der Donau beigetragen haben.

Es werden 55 wichtige wissenschaftliche Arbeiten erwähnt, die von 54 Fachleuten im Zeitraum 1931-2006 veröffentlicht wurden. România).

REZUMAT: Stadiul actual al cercetărilor fitocenologice în Defileul Dunării (Banat,

Autorul realizează un scurt istoric al cercetărilor fitocenologice din Defileul Dunării, amintind, cronologic, după anul apariţiei lucrărilor, botaniştii care au contribuit prin cercetările lor la cunoaşterea vegetaţiei cormofitelor din acest sector al Dunării.

Sunt evidenţiate 55 lucrări ştiinţifice importante scrise de 54 specialişti în intervalul 1931-2006. 


\section{INTRODUCTION}

The expected construction of the "Iron Gates" hydro-electric and navigation system motivated a number of research teams (made up of geologists, geographers, hydrologists, botanists, zoologists, ecologists, etc.) to undertake studies aiming at evincing the habitat diversity and the specificity of the territories to be flooded, along with other areas in their near vicinity. That is how, beginning with 1968, dozens of papers were published on the local flora and vegetation, with nearly 200 coeno-taxons being described, a tenth of them being endemic.

The area whose vegetation constitutes the subject matter of the present paper is the Danube River segment known as the Danube Gorge, especially in its most well-known part, the "Iron Gates". Most of that area is included in the "Iron Gates" National Park.

\section{MATERIALS AND METHODS}

The paper is based on the bibliography mentioned below.

\section{RESULTS AND DISCUSSIONS}

The Danube Gorge is an area where elements of Carpathian vegetation intermingle with Pannonian, Balkan and Sub-Mediterranean ones. Most of the local phyto-coenoses, both ligneous and gramineous species share an obvious thermophilous character and rarity - which was noted as early as a century ago. That is why among the earliest proposals of natural reserves in Romania (made in 1920) were "The Gorge Pass in Banat", or "Danube's Gorge with forest and rock vegetation" and "The Iron Gates - the slopes at Gura Văii". To those reservations of botanical interest (Cazanele Mari and Cazanele Mici, Gura Văii - Vârciorova) others were added in time: Oglănicului Valley, Valea Mare/Mare Valley, Cracul Găioara, Cracul Crucii, Faţa Virului, Vărănic Hill, Duhovnei Hill - all parts of the "Iron Gates” Natural Park (covering 115,655.85 hectares), a protected natural area since 1998.

The phyto-sociological study of the Danube Gorge area was initiated in 1931, with the phyto-geographic excursion (of an international team) organised by Borza A. on the following itinerary: Sviniţa - Tricule - Drencova - Cazane - Orşova - Ada-Kaleh Isle - Vârciorova Gura Văii.

The first paper following the excursion was published by Domin (1932); it included phyto-sociological input on the area Cazane - Ada Kaleh Isle - Gura Văii. Călinescu (1935, 1957) provided information on the biodiversity of the former Ada Kaleh Isle and on "şibliac", a type of shrubbery specific for that segment of the Danube. Popescu and Samoilă (1962) wrote a description of the Danube Gorge, both in floristic and in phyto-coenological terms.

Costache (1967) reveal some phyto-geographic elements between Orşova and Baziaş. Raţiu (1968) ofer information regarding the Ada-Kaleh Island vegetation. Sanda et al. (1968) introduced palustral coenoses in the gorge, while Csürös et al. $(1968,1969)$ and Pop et al. (1969) described their investigations on vegetal aggregation in the Orşova - Eşelniţa area. Boşcaiu and Resmeriţă (1969) focused their research on the xerophilous gramineous alluvial vegetation, while Anghel et al. (1970) wrote about the division into zones of the ligneous and gramineous vegetation in the "Iron Gates" area. Păun et al. (1970) the vegetation in the Berzasca - Pescari area. Stefureac (1970) complete the flora and vegetation located at Porțile de Fier with new species and vegetal associations. Morariu et al. $(1970,1973)$ wrote about the vegetation of the "Iron Gates" and Moldova Veche Isle areas, while Dihoru et al. (1970, 1973) about that extant between Valea (i.e. valley) Mraconiei and Depresiunea (i.e. depression) 
Dubova; Coldea et al. (1970) described the beech forests in the area between Eşelniţa Valley and Mraconiei Valley; Ştefureac and Popescu (1970) described the coenoses of Stipa bromoides. Şerbănescu and Sanda (1970) introduced the river-meadow and hill-side vegetations in between Cazanele Mari and Plavişeviţa, while Schneider-Binder et al. (1970, 1971) highlighted the features of the saxicolous vegetation in the Eşelniţa - Tricule area. Mišič (1971) light shed on the relict vegetation in the gorge, while Boşcaiu et al. (1971) did the same on the characteristic features of the meso-xerothermal ligneous vegetation of the order OrnoCotinetalia. Todor et al. (1971) contributed to increase the knowledge of the flora and vegetation of the Danube Gorge area in between the town of Moldova Veche and the village Pojejena. Purcelean et al. (1971) researched Porţile de Fier forest vegetatin. Resmeriţă et al. (1971, 1972) realised a mapping of the vegetation in the sectors Eşelniţa - Mraconia and Cazane - Tricule, as well as a study of the nitrophilous vegetation. The anthropogenous, ruderal vegetations, along with the pratal and palustral ones, were also studied by Raclaru and Alexan (1973).

Roman (1974) worked out a rather comprehensive study of the vegetation in the respective sector of the Danube, with many descriptions of coenotaxons that were new for both science and Romanian botany. Also in 1974 Stere and Coste reveal botanical aspects from Valea Mare-Moldova Nouă natural reservation. Popescu and Ştefureac (1976) published their findings on the vegetation in the Sviniţa - Tricule sector, while Grigore and Coste (1978) reveal the vegetation between Moldova Veche and Pescari. Sanda and Popescu (1980) describe the water and palustral vegetation in the area of the "Iron Gates" reservoir. Oprea et al. (1982), and Nedelcu and Sanda (1983) added new studies to the descriptions about the extant forest vegetation. Arsene et al. (2006) focused their study on thermophilous shrubs. The most valuable contribution to the knowledge of the vegetation in the "Iron Gates" area was made by Matacă, who described in several papers (published between 2000-2005), including her doctoral thesis, the whole of the respective vegetation, from aquatic, palustral, or saxicolous coenoses to forests.

\section{CONCLUSIONS}

This study reveals the fact that the vegetation and flora of the "Iron Gates" Gorges is well studied, both before the "Iron Gates" Dam construction (more than half of a century ago) and after the formation of the new anthropogenic lake, especially after the establishment of the "Iron Gates" Natural Park.

Based on these old and new data in the area of interest, different comparisons regarding the vegetation can be made and the evolution of phytocoenosis can be revealed.

\section{ACKNOWLEDGEMENTS}

The author thank to Mr. Ungurean S. for the paper translation in English and to Mrs. Schneider-Binder E. for the translation of the German abstract. 


\section{REFERENCES}

1. Anghel G., Turcu G., Ciocârlan V. and Doniţă N., 1970 - Zonarea vegetaţiei lemnoase şi ierboase de la Porţile de Fier (sectorul Cozla - Berzasca), Lucrările ştiinţifice ale Institutului Agronomic Bucureşti, seria Agronomie, 13, 413-418. (in Romanian)

2. Arsene G. G., Coste I., Neacşu A. G., Avrămuţ O. I. and Fărcăşescu A., 2006 - A syntaxonomic review of thermophilous shrub communities (Syringo-Carpinetum orientalis) in SW Romania in Gafta D. and Akeroyd J. R., Nature conservation: Concepts and practice, Springer Verlag Berlin Heidelberg, 142-168.

3. Borza A., 1931 - Die Vegetation und Flora Rumäniens, I Partie, Guide de la sexiéme Excursion Phytocenologique International en Roumanie, Cluj-Napoca, 1-55. (in German)

4. Boşcaiu N. and Resmeriţă I., 1969 - Vegetaţia ierboasă xerofilă de aluviuni din sectorul Valea Eşelniţa - Valea Mraconiei la Defileului Dunării, Studii şi cercetări de biologie, Seria botanică, București, 21, 3, 209-216. (in Romanian)

5. Boşcaiu N., Lupşa V., Resmeriţă I., Coldea G. and Schneider-Binder E., 1971 - Vegetaţia lemnoasă mezo-xerotermă (Orno-Cotinetalia) din Defileul Dunării, Ocrotirea Naturii, Bucureşti, 15, 1, 49-55. (in Romanian)

6. Călinescu I. R., 1935 - Contribuții la studiul insulei Ada-Kaleh, Arhiva Olteniei, XIV, 7-78. (in Romanian)

7. Călinescu R., 1957 - Contribuţii la studiul şibliacului în R. P. Română, Revista Pădurilor, LXX, 2, Bucureşti, 76-84. (in Romanian)

8. Călinescu R. and Iana S., 1964 - Consideraţiuni biogeografice asupra Defileului Dunării, Analele Universităţii Bucureşti, Seria Geologie-Geografie, Bucureşti, XIII, 1, 151-168. (in Romanian)

9. Coldea G., Boşcaiu N., Lupşa V., Plămadă E. and Resmeriţă I., 1970 - Vegetaţia făgetelor din sectorul Valea Eşelniţa - Valea Mraconiei al Defileului Dunării, Studii şi cercetări de biologie, Seria Botanică, Bucureşti, XXII, 6, 467-474. (in Romanian)

10. Costache N., 1967 - Consideraţii fitogeografice asupra Defileului Dunării între Orşova şi Baziaş, Analele Universităţii Bucureşti, Seria ştiinţele naturii, Geologie-Geografie, Bucureşti, XVI, 2, 157-162. (in Romanian)

11. Csűrös S., Pop I., Hodişan I. and Csürös-Kaptalan M., 1968 - Cercetări floristice şi de vegetaţie între Orşova şi Eşelniţa, Contribuţii botanice, Cluj, 277-312. (in Romanian)

12. Csűrös S., 1969 - Aspecte de vegetaţie de pe Valea Eşelniţa (Munţii Almăjului, Banat), Contribuţii botanice, Cluj, 235-243. (in Romanian)

13. Dihoru G., Andrei M. and Cristurean I., 1970 - Date preliminare despre flora şi vegetaţia ierboasă din Valea Mraconiei şi Cazanele Mari ale Dunării, Acta botanica Horti Bucurestiensis, Bucureşti, 1968, 207-214. (in Romanian)

14. Dihoru G., Andrei M. and Cristurean I., 1973 -Vegetaţia dintre Valea Mraconiei - Depresiunea Dubova, Acta botanica Horti Bucureştiensis, Bucureşti, 1972-1973, 353-423. (in Romanian)

15. Domin K., 1932 - Domugled, Kazanski sontesky, Ada Kaleh a Varciorova, Publications de la Faculte de Sciences de Universite Charles, Praha, 122-144. (in Czech)

16. Grigore S. and Coste I., 1978 - Cercetări asupra vegetaţiei dintre Moldova Veche şi Pescari (judeţul Caraş-Severin), Banatica, Caiete de Ştiinţe naturale, Reşiţa, 7, 173-189. (in Romanian)

17. Matacă S. Ş., 2000 - Istoricul cercetărilor botanice din teritoriul Parcului Natural Porţile de Fier, Studii şi Comunicări, Ştiințele Naturii, Craiova, XVI, 85-89. (in Romanian)

18. Matacă S. Ş., 2002a - Arondarea fitogeografică a teritoriului Parcului Natural Porţile de Fier, Marisia, Studia Scientiarum Naturale, Târgu-Mureş, XXVI, 151-160. (in Romanian) 
19. Matacă S. Ş., 2002b - Vegetaţia forestieră şi arbustivă din Parcul Natural Porţile de Fier, Drobeta, XI, 296-306, Drobeta Turnu Severin. (in Romanian)

20. Matacă S. Ş., 2002c - Vegetaţia saxicolă din Parcul Natural Porţile de Fier, Marisia, Studia Scientiarum Naturale, XXVI, Târgu-Mureş. (in Romanian)

21. Matacă S. Ş., 2003a - Contribuţii privind clasa Thlaspietea rotundifoli Br-Bl, 1948 în arealul Parcului Natural Porţile de Fier, Studii şi Comunicări, Ştiințele Naturii, Muzeul Olteniei, XIX, Craiova. (in Romanian)

22. Matacă S. Ş., 2003b - Contribuţii privind vegetaţia acvatică şi palustră din arealul Parcului Natural Porțile de Fier, Drobeta, XII, 218-238, Drobeta Turnu-Severin. (in Romanian)

23. Matacă S. Ş., 2003c - Études géosymphytosociologiques dans le Parc Naturel „Porţile de Fier” (Roumanie), Contribuţii botanice, XXXVIII, 2, 57-66, Cluj-Napoca. (in French)

24. Matacă S. S.,. 2004a - Asociaţii endemice din Parcul Natural Porţile de Fier, Drobeta, Seria Ştiințe Naturale, XIV, 15-34, Craiova. (in Romanian)

25. Matacă S. Ş., 2004b - Noi asociaţii în arealul Parcului Natural Porţile de Fier, Argesis, Studii şi Comunicări, Ştiinţe Naturale, 12, 65-78, Piteşti. (in Romanian)

26. Matacă S. Ş., 2005 - Flora şi vegetaţia ocrotită din Parcul Natural Porţile de Fier, Ecos, Piteşti, 82-95. (in Romanian)

27. Matacă S. Ş., 2005a - Parcul Natural Porţile de Fier. Floră, vegetaţie şi protecţia naturii, Edit. Universitaria, Craiova, 550. (in Romanian)

28. Matacă S. Ş., 2005b - Contributions concervant l'ordre Fagetalia sylvaticae, Pawlowski in Pawlowski et al. 1928 dans le territoire du Parc Naturel "Porţile de Fier", Contribuții Botanice, XL, 77-87, Cluj-Napoca. (in French)

29. Mišić V., 1971 - Reliktna vegetacija Resavske klisure, Arhiv bioloških nauka, 23, 1-2, 17-18, Beograd. (in Serbian)

30. Morariu I. and Danciu M., 1970 - In der Gegend des Eisernen Tores (Porţile de Fier) gemeldete Pflanzenasoziationen, Revue Roumaine de Biologie, Botanique, XV, 6, 419-429, Bucureşti. (in German)

31. Morariu I., Danciu M. and Ularu P., 1973 - Die Vegetation der Flussinsel Moldova Veche, Acta botanica Horti Bucurestiensis, 1972-1973, 465-499, Bucureşti. (in Romanian)

32. Nedelcu G. A. and Sanda V., 1983 - Vegetaţia lemnoasă din zona lacului de acumulare "Porţile de Fier" (Baziaş - Drobeta-Turnu Severin), Acta botanica Horti Bucurestiensis, 1981-1982, 147158 , București. (in Romanian)

33. Oprea I. V., Oprea V. and Purdelea L., 1982a - Contribuţii la sintaxonomia făgetelor din proiectatele parcuri naţionale din Munţii Banatului, in Preda V. and Boşcaiu N. - Făgetele carpatine, Cluj-Napoca, 206-216. (in Romanian)

34. Oprea I. V., Oprea V. and Purdelea L., 1982b - Rezervaţii forestiere din sud-vestul României şi vegetaţia acestora, Ocrotirea Naturii şi a Mediului Înconjurător, București, 26, 1, 2, 97-99. (in Romanian)

35. Păun M., Popescu G., Cârţu M. and Cârţu D., 1970 - Aspecte din vegetaţia dintre Berzeasca şi Pescari (jud. Caraş-Severin), Analele Universităţii Craiova Seria Bioogie - Ştiinţe Agricole, Craiova, 61-70. (in Romanian)

36. Pop I., Hodişan I. and Csürös S., 1969 - Aspecte de vegetaţie de pe Valea Eşelniţa (Munţii Almăjului, Banat), Contribuţii Botanice, 233-243, Cluj. (in Romanian)

37. Popescu P. C. and Samoilă Z., 1962 - Ghid geobotanic pentru Banat, Societatea de Ştiinţele Naturii şi Geografie, Secţia Botanică, Bucureşti, 82. (in Romanian)

38. Popescu A. and Ştefureac T. I., 1976 - Vegetations Forschungen aus dem Sektor Sviniţa-Tri Kule-Eisernes Tor Rumäniens, Acta botanica Horti Bucurestiensis, 1975-1976, 341-368, București. (in German) 
39. Purcelean S., Lupe I. Z., Leandru V. and Cambir F., 1971 - Cercetări asupra vegetaţiei forestiere din zona de la Porţile de Fier care va fi inundată prin crearea lacului de acumulare, Studii şi cercetări Institutul de Cercetări Silvice, Bucureşti, Sect. 1, 28 (Silvic), 9-32. (in Romanian)

40. Raclaru P. and Alexan M., 1973a - Vegetaţia pajiştilor şi cea ruderală din Defileul Dunării, Baziaş-Pojejena, Studii și cercetări de biologie, Seria Botanică, 25, 3, 205-214, Bucureşti. (in Romanian)

41. Raclaru P. and Alexan M., 1973b - Asociaţii vegetale palustre din Defileul Dunării între Baziaş şi Pojejena, Studii și Cercetări de biologie, Seria Botanică, 25, 2, 131-139, Bucureşti. (in Romanian)

42. Raţiu O., 1968 - Cercetări fitocenologice asupra vegetaţiei ierboase pe insula Ada-Kaleh, Contribuții Botanice, 189-208, Cluj. (in Romanian)

43. Resmeriță I., Vicol E. C., Coldea G. and Schneider-Binder E., 1971 - Vegetaţia nitrofilă din sectoarele Eşelniţa-Mraconia şi Cazane-Tricule (Defileul Dunării), Comunicări de botanicăa, Bucureşti, XII, 331-348. (in Romanian)

44. Resmeriţă I., Vicol E. C., Boşcaiu N., Coldea G. and Täuber F., 1972 - Cartarea vegetaţiei din sectorul Valea Eşelnița-Trei Cule (Defileul Dunării), Studii și Cercetări de biologie, Seria Botanică, 24, 3, 213-220, Bucureşti. (in Romanian)

45. Roman N., 1974 - Flora şi vegetaţia din sudul Podişului Mehedinţi, Edit. Academiei Române, București, 222. (in Romanian)

46. Sanda V., Şerbănescu G. and Zăvoianu I., 1968 - Aspecte ale florei şi vegetaţiei palustre din Clisura Cazanelor, Studii și Cercetări de biologie, Seria Botanică, 20, 3, 217-224, Bucureşti. (in Romanian)

47. Sanda V. and Popescu A., 1980 - Vegetaţia acvatică şi palustră din zona lacului de acumulare „Porţile de Fier” (Baziaş - Drobeta-Turnu Severin), Contribuții Botanice, 161-175, ClujNapoca. (in Romanian)

48. Schneider-Binder E., Boşcaiu N., Coldea G., Lupşa V., Plămadă E., Resmeriţă I. and Stoicovici L., 1970 - Zur Felsenvegetation der Sektoren Eşelniţa-Mraconia und Kazanpass-Tricule (Durchbruchtal der Donau), Revue Roumain de Biologie, Botanique, 15, 5, 311-322, Bucureşti. (in German)

49. Schneider-Binder E., Boşcaiu N., Coldea G., Lupşa V., Plămadă E. and Resmeriţă I., 1971 Zwei neue xerotherme Felsengesellschaften aus dem Durchbruchtal der Donau, Revue Roumain de Biologie, Botanique, 16, 2, 97-103, Bucureşti. (in German)

50. Stere G. and Coste I., 1974 - Aspecte botanice din rezervaţia naturală Valea Mare-Moldova Nouă, Ocrotirea Naturii, 18, 2, Bucureşti, 159-166. (in Romanian)

51. Şerbănescu G. and Sanda V., 1970 - Cercetări asupra vegetaţiei de luncă şi dealuri între Cazanele Mari şi Plavişeviţa, Studii şi Cercetări de Biologie, Seria Botanică, 22, 3, București, 171-178. (in Romanian)

52. Ştefureac T., 1970 - Cercetări asupra florei şi vegetaţiei de la Porţile de Fier, Analele Universităţii Bucureşti, Biologie vegetală, 19, 193-204, Bucureşti. (in Romanian)

53. Ştefureac T. and Popescu A., 1970 - Recherches sur les phytocenoses a Stipa aristela L. du sudest de la Roumanie, Revue Roumain de Biologie, Botanique, 15, 5, 323-350, Bucureşti. (in French)

54. Todor I., Gergely I. and Bârcă C., 1971 - Contribuţii la cunoaşterea florei şi vegetaţiei din zona Defileului Dunării între oraşul Moldova Veche şi comuna Pojejena (jud. Caraş-Severin), Contribuţii Botanice, 203-256, Cluj-Napoca. (in Romanian)

55. ***, 1972 - Atlasul complex „Porţile de Fier”, Edit. Academiei R. S. România, Bucureşti, Vulcănescu R. (coordinator), 260. (in Romanian)

56. ***, 2013 - Planul de management al Parcului Natural Porţile de Fier. (in Romanian) 